\title{
Г.Н. Мокшин
}

\section{АКТУАЛЬНЫЕ ПРОБЛЕМЫ ИЗУЧЕНИЯ ИСТОРИИ РУССКОГО НАРОДНИЧЕСТВА НА СТРАНИЦАХ ЖУРНАЛА «ВЕСТНИК РОССИЙСКОГО УНИВЕРСИТЕТА ДРУЖБЫ НАРОДОВ. СЕРИЯ: ИСТОРИЯ РОССИИ». 2008-2017 гГ.}

\begin{abstract}
Статья посвящена анализу публикаций на страницах «Вестника Российского университета дружбы народов. Серия: История России» за последние десять лет и установлению связи их проблематики с общими тенденциями развития отечественного народниковедения. Прежде всего речь идет о разработке общей парадигмы народничества как идеологии самобытной модернизации России в рамках научной школы профессора В.Ф. Антонова.

Ключевые слова: историография; народничество; интеллигенция; реформаторский демократизм; свобода личности.
\end{abstract}

Отечественным исследователям русского народничества хорошо известна сложившаяся на кафедре истории России Российского университета дружбы народов (РУДН) научная школа профессора В.Ф. Антонова, 100 -летие которого будет отмечаться в следующем году. Представители научной школы (доктора исторических наук Р.А. Арсланов, В.В. Блохин, В.В. Зверев, В.А. Исаков, Н.А. Тюкачев и др.) внесли существенный вклад в становление современного народниковедения [1]. Во многом благодаря их усилиям издаваемый с 2002 г. в Российском университете дружбы народов профильный журнал превратился в один из ведущих центров изучения истории и историографии русского народничества.

Несмотря на очевидные успехи современного поколения народниковедов, связанные с утверждением к середине 2000-х гг. нового подхода к интерпретации явления русского народничества [2], проблема концептуализации его истории по-прежнему сохраняет свою актуальность. Большинство историков по понятным причинам заняты изучением отдельных течений народничества и их представителей, оставляя авторам обобщающих исследований вопросы общей типологии и периодизации истории народничества, а также разработку нового понятийного аппарата. Только, к сожалению, такие исследования можно пересчитать по пальцам.

Одна из особенностей новейшего периода изучения народничества - повышенный интерес исследователей к историографии проблемы. В «Вестнике Российского университета дружбы народов. Серия: История России» за прошедшее десятилетие опубликован ряд статей, посвященных проблемам изучения революционного и легально-реформаторского народничества и их последователей в начале XX в.

Дореволюционная консервативная историография революционного народничества анализируется в статье Н.А. Тюкачева (Брянск) - одного из ведущих современных историографов левого крыла народничества 1860-1880-х гг. [3]. Долгое время считалась, что труды консерваторов не имеют значения из-за своей крайней тенденциозности. Тюкачев оспаривает эту точку зрения, доказывая, что дать объективное толкование народнического движения возможно только при внимательном непредвзятом изучении всех его трактовок и концепций. Ведь и среди «охранителей» были люди, хорошо знающие радикальную русскую интеллигенцию, как, например, бывший народоволец Лев Тихомиров. Кроме того, труды работников охранных структур содержат огромный фактических материал по истории русского освободительного движения [4. С. 87].

В целом мы согласны с выводами Н.А. Тюкачева. Только стоит заметить, что упомянутые выше материалы предназначались для дискредитации революционеров и не всегда их можно рассматривать в качестве «ценных источников». Например, следствие по делу Дм. Каракозова установило, что он, будучи больным туберкулезом, употреблял наркотики. Понятно, какие далеко идущие выводы можно сделать из этого факта. Но приблизит ли это нас к пониманию природы русского терроризма?

Историография правого (реформаторского) народничества - еще одна актуальная тема современного народниковедения. До конца 1980-х гг. «мирные» народники находилось в тени революционного народничества, так как олицетворяли процесс его перерождения в либеральных мелкобуржуазных «реакционеров». Изучению историографического феномена «либеральное народничество» от его возникновения и до наших дней посвящены две статьи В.В. Зверева.

По мнению Зверева, деление народников на «славянофилов» и «либералов» (западников) зародилось еще в конце 1870-х гг. Но теоретическое обоснование концепта «либеральные народники» дали русские марксисты в рамках так называемого классового подхода. Подробно проанализировав концепции народничества Г.В. Плеханова и В.И. Ленина, автор приходит к выводу, что они носили «оценочный» (не исследовательский) характер, так как были подчинены логике политического противостояния марксистов с народниками. Правда, в начале XX в. в трудах А.Н. Потресова и Ю.О. Мартова народничество уже трактовалось как 
феномен группового самосознания интеллигенции. Но и у них, как у всех марксистов, отсутствовал анализ мировоззренческих установок народничества, что, по убеждению автора, является ключом к пониманию сущности этого феномена пореформенной общественной жизни России [5. С. 66, 68-69].

Историографию советской эпохи Зверев анализирует сквозь призму накопления знаний о типологии течений правонародничестой мысли в трудах Б.П. Козьмина, Е.Е. Колосова, В.Г. Хороса, В.И. Харламова, Б.П. Балуева и др. К началу 1980-х гг. это приведет исследователей к пониманию того, что факты противоречат господствовавшей тогда ленинской концепции народничества как идеологии, отражавшей интересы и настроения крестьянства. Сам автор в монографии «Реформаторское народничество и проблема модернизации России» (1997) будет доказывать, что народники как представители радикальной отечественной интеллигенции выражали собственное (субъективное) видение происходящих в стране модернизационных процессов и пытались оказать на них влияние [6. С. 22, 24].

В конечном итоге Зверев, в пику историкам-марксистам, формулирует тезис о противоположности доктрин либерализма и народничества. «Либерализм, пишет исследователь, - ориентирован на свободу личности, народничество на первое место ставит коллектив личностей. Либерализм главным условием развития социума считает конкуренцию и столкновение интересов в различных областях жизни, народничество обеспечение достойных условий существования всем членам общества» [7. С. 17].

Данный подход, безусловно, способствует утверждению нового понимания народничества как идеологии некапиталистической (антибуржуазной) модернизации страны. Однако тезис о полной несовместимости народничества и либерализма, на наш взгляд, звучит слишком категорично. Разве противоположность идеалов не исключает общих тактических задач - борьбы за расширение политических прав и свобод? Сам же автор отмечает гибкость (пластичность) народничества, которое в борьбе за общественное влияние сумело ассимилировать различные, в том числе противоположные, идеи и методы.

История становления современной историографии правого народничества стала предметом изучения Г.Н. Мокшина (Воронеж). За точку отсчета автор берет труды московского историка В.И. Харламова, который еще в конце 70-х гг. ХХ в. разработал первую научно обоснованную периодизацию «либерального народничества». Вопреки сложившейся традиции, она начиналась не с 1881 г., а с рубежа 1850/1860-х гг. - от А.И. Герцена и Н.Г. Чернышевского [8. С. 47]. Кстати, обоснование тезиса о том, что основоположники народничества считали более предпочтительным мирный путь общественных преобразований России, принадлежит В.Ф. Антонову.

В статье анализируются попытки Харламова рассмотреть процесс становления и эволюции идеологии позднего народничества исходя из особенностей мировосприятия его идеологов, поскольку, по справедливому утверждению историка, внутренние факторы раз- вития народнической мысли довлели над внешними. Еще одна заслуга Харламова - разработка истории так называемого «культурнического народничества», расширяющая представления исследователей о типологии течений классического русского народничества. Правда, развитие идеологии культурно-народнического направления Харламов связывал с деятельностью публицистов «Недели» И.И. Каблица и Я.В. Абрамова (отсюда ее второе название - «неделизм»). Поэтому эволюция этого течения ограничивалась второй половиной 1880-х гг. [Там же. С. 48].

Историографии неонародничества, точнее, его правого крыла - партии народных социалистов, посвящена статья М.Н. Мосейкиной. Автор отмечает значительный интерес к идеологии трудовой народносоциалистической партии со стороны современных исследователей (Н.Д. Ерофеев, А.В. Сыпченко, О.Л. Протасова и др.). В советской историографии преобладала точка зрения, что партия энесов возникла в результате отделения от эсеров и ее главное отличие - умеренность в вопросе тактики общественных преобразований. Новое поколение народниковедов, по сути, опровергает этот подход. Энесы - идейные наследники левого крыла легально-реформаторского народничества, возглавляемого Н.К. Михайловским (наверное, не случайно их главный теоретик - А.В. Пешехонов похоронен рядом с ним). В статье Мосейкиной рассматриваются выявленные исследователями теоретические положения программы энесов (этатизм, национализация, критическое отношение к марксизму и др.), позволяющие по-новому оценить вклад народных социалистов в развитие идеологии неонародничества [9].

В 2014-2015 гг. в журнале опубликованы две статьи молодой исследовательницы Н.А. Жуковой о западногерманской историографии М.А. Бакунина - одного из самых ярких идеологов анархизма. По замечанию Н.M. Пирумовой, зарубежное бакуниноведение превосходит отечественное, поскольку значительная часть революционной деятельности главного русского анархиста была связана с Европой [10. С. 12]. Поэтому интерес к немецкой историографии данной темы вполне оправдан.

Автор отслеживает процесс становления и развития западногерманской историографии анархизма М.А. Бакунина от начала до 80-х гг. ХХ в. Установлено, что до революции 1918 г. он интересовал авторов прежде всего как революционер, после - как критик марксизма за его централизм и склонность к идее диктатуры. Не случайно большинство авторов (П. Вебер, Я. Каттепоэль, Ф. Витткоп и др.) принадлежат к либеральному течению. Интересно, что наряду с критикой анархизма многие немецкие исследователи отмечают гуманизм М.А. Бакунина и его соратника П.А. Кропоткина, что, по мнению Жуковой, является одной из главных причин популярности анархических идей в Германии $[11 ; 12$. С. 54].

Большинство наших авторов обратились к историографии народничества, будучи зрелыми исследователями, хорошо знакомыми не только с литературой, но и с «первоисточниками». И так уж сложилось, что сфера их научных интересов связана с историей пра- 
вого (нереволюционного) крыла народничества, активно и плодотворно разрабатываемой новым поколением народниковедов с середины 1990-х до начала 2010-х гг. Именно на этот период приходится наибольшее количество докторских диссертаций по данной проблематике [13-15].

Отличительная особенность правого народничества - отсутствие у него партийных организаций, подобных тем, что были у революционных народников, и, соответственно, программ совместной деятельности. Это обстоятельство повлияло на преобладание в изучении его идеологии и практики так называемого персонифицированного подхода. В «Вестнике Российского университета дружбы народов. Серия: История России» в рассматриваемый период были опубликованы отдельные статьи о Н.К. Михайловском и В.Г. Короленко (В.В. Блохина), Н.Ф. Даниельсоне и Г.П. Сазонове (В.В. Зверева). И еще в трех статьях (Г.Н. Мокшина, А.М. Пашкова, Р.А. Арсланова и А.Л. Климашина) освещались взгляды и деятельность некоторых видных народников-культурников 1880-1890-х гг.

Самым крупным теоретиком легально-реформаторского народничества по праву считается Н.К. Михайловский. В 2010 г. В.В. Блохин - один из лучших знатоков идейного наследия «властителя дум» нескольких поколений демократической интеллигенции опубликовал обстоятельное исследование, посвященное проблеме становления его мировоззрения. Большинство предшественников Блохина настаивали на том, что взгляды Михайловского (как и всех народников) страдали эклектизмом. Автор, напротив, доказывает его целостный характер. Он подробно анализирует влияние на формирование мировоззрения Михайловского идей Д.И. Писарева, Н.Д. Ножина, Г.З. Елисеева и выявляет его отличительные черты: рационализм, сциентизм, социальный реформизм, политицизм, социализм и, наконец, веру в «идейное предводительство интеллигенции над народом» [16. С. 104]. Только странно, что в этом обстоятельном перечне не нашлось места главной доминанте самосознания народнической интеллигенции - демократизму. Впрочем, по мнению автора, Михайловский был единственным из народников, кто не верил в созидательные возможности народа [Там же. С. 105].

В другой своей статье В.В. Блохин рассматривает биографию и взгляды одного из соратников Н.К. Михайловского, известного народнического писателя В.Г. Короленко. Он также считал высшей ценностью борьбу за права человека и был далек от идеализации народа. Но, в отличие от Михайловского, Короленко верил в то, что русский народ обязательно рано или поздно станет сознательным творцом своей исторической судьбы [17. С. 35].

В.В. Зверев в статье об известном народническом экономисте Н.Ф. Даниельсоне исследует особенности его восприятия марксизма (в свете позитивизма) и устанавливает причины, по которым народнические позиции переводчика «Капитала» и друга К. Маркса и Ф. Энгельса остались непоколебимыми [18]. Еще одна статья исследователя народничества посвящена Г.П. Сазонову - одному из идеологов «малых дел» 1890-х гг.
В начале XX в., будучи попечителем Петропавловской больницы Санкт-Петербурга, он наконец получил возможность практического применения популярной народнической теории. Проанализировав отчет Сазонова о его работе, Зверев на этом конкретном примере пришел к неутешительному для народников-культурников выводу, что предлагаемая ими программа мер могла улучшить ситуацию с народным здравоохранением, но не изменить. Для этого, по мнению историка, требовалась новая государственная политика, и прежде всего постановка вопроса о бесплатном медицинском обслуживании населения [19. С. 37].

Теоретическая и практическая деятельность главных теоретиков культурничества И.И. Каблица, Я.В. Абрамова и С.Н. Кривенко анализировалась в статье Г.Н. Мокшина. В отличие от В.В. Зверева, он доказывает особую роль культурнических идей в эволюции народничества 1880-1890-х гг. Именно теоретики «малых дел», по его мнению, сумели раздвинуть узкие рамки интеллигентности, заданные идеологами революционного народничества, создав положительный образ нового типа интеллигента - «культурного» или «социального» работника (врача, учителя, технолога, агронома, статистика). Тем самым они способствовали превращению вчерашних бунтарей и революционных пропагандистов в созидательную общественную силу [20. С. 23-24].

Краеведческая деятельность ссыльного народникарасколоведа А.С. Пругавина и исследователя Русского Севера С.А. Приклонского в 70-80-е гг. XIX в. рассмотрена в статье историка из Петрозаводска А.М. Пашкова. Автор находит у этих народников ряд общих черт, прежде всего это оппозиционный характер их научных изысканий. Данное обстоятельство позволило Пашкову отметить их весомый вклад не только в развитие краеведения в Архангельской и Олонецкой губерниях, но и в становление местной интеллигенции [21. С. 117-120].

Взгляды народников 1890-х гг. на положение русских крестьян-переселенцев в Среднюю Азию затрагиваются в статье Р.А. Арсланова и А.Л. Климашина. На примере публикаций народника-экономиста К.Р. Качоровского и ведущего статистика Туркестанского края И.И. Гейера исследователи выделяют особенности народнического подхода к решению проблемы адаптации русских мигрантов (необходимость укрепления среди них общинных порядков и культурная помощь со стороны местной русской интеллигенции) [22. C. 351-353].

Изучение политических биографий и взглядов ведущих теоретиков правого народничества, безусловно, способствует выявлению общих тенденций в развитии его идеологии и практики. Но вопрос о разработке общей типология течений и периодизации истории данного направления русского народничества пока остается открытым. Рассмотрим основные разногласия в этой области между исследователями на примере статей Р.А. Арсланова, В.В. Блохина, В.В. Зверева и Г.Н. Мокшина.

Все упомянутые исследователи согласны с тем, что правое народничество нельзя называть «либеральным», так как это искажает смысл его доктрины обществен- 
ных преобразований, направленной на построение социально однородного общества. (Конечная цель всех народников и главный мотив их деятельности торжество «социальной справедливости», а «свобода» одно из условий ее достижения.) Однако на полной противоположности «либерализма» и «народничества» настаивает только В.В. Зверев. Его коллеги Р.А. Арсланов и В.В. Блохин, напротив, доказывают возможность их синтеза. Об этом, в частности, свидетельствует разработка тем же Н.К. Михайловским доктрины «либерального социализма» - результат напряженных поисков им путей скорейшей демократизации страны [23. C. 29].

На наш взгляд, ключ к разрешению этих разногласий - в признании существования в правом народничестве двух противоположных флангов: правого, консервативного, делающего ставку на социальные преобразования по формуле «для народа и через народ», и левого, либерального, который ставит на первое место борьбу за политические свободы «для народа, но без народа» (т.е. посредством интеллигенции). На возможности существования «консервативного народничества» (И.И. Каблица и Кㅇ) больше всех настаивает В.В. Зверев [24], «либерального» (Н.К. Михайловского) - В.В. Блохин [25. С. 131]. Разумеется, речь идет не о доктрине, а о тактике ее осуществления.

Еще одним камнем преткновения является периодизация истории легально-реформаторского народничества. Эта проблема рассмотрена в одной из статей Г.Н. Мокшина в контексте истории так называемого «культурного» (умеренно правого) народничества. Современные историки обычно используют периодизацию правого народничества, предложенную В.И. Харламовым. Она включает четыре этапа: зарождение, становление, эволюцию и кризис, которым соответствуют 60-е, 70-е, 80-е и 90-е гг. XIX в. [20. С. 21].

Собственно, проблема заключается не в уточнении дат, а в различной интерпретации сути «культурной работы» и ее места в эволюции идеологии позднего народничества. Например, В.В. Зверев вслед за В.И. Харламовым доказывает, что увлечение «культурничеством» и теорией «малых дел» вело народников к отказу от социалистических идеалов и примирению с действительностью, что в середине 1890-х гг. спровоцировало кризис и раскол народнического движения [5. С. 57]. Г.Н. Мокшин с такой оценкой культурничества категорически не согласен и настаивает на том, что у народников был шанс реформировать народничество в духе теории «органической культурной работы» С.Н. Кривенко. Однако возможность объединить «культурников» и «политиков» во имя общей цели была упущена из-за неуступчивости Н.К. Михайловского [20. С. 24-25].

Очевидно, что исследователи истории правого народничества находятся внутри народнического дискурса, включая автора этих строк, что мешает им выработать консолидированную позицию. С другой стороны, наличие противоположных подходов позволяет рассматривать данную проблематику с разных сторон, что способствует более объективному ее освещению.

Идея синтеза либерализма и народничества как условия выработки национальной модели модерниза- ции страны, высказанная Р.А. Арслановым и В.В. Блохиным в спорах о феномене «либерального народничества», получила развитие в исследовательском проекте кафедры истории России РУДН «Эволюция реформаторской демократической мысли России во второй половине XIX - начале XX вв.: модели развития, историография и методы исследования» (грант РГНФ) [26]. Цель проекта заключалась в том, чтобы, опираясь на анализ особенностей отечественного либерализма (антибуржуазность, признание необходимости сохранения крестьянской общины, отстаивание идеи сильного социального государства и др.), обосновать его идеологическую совместимость с демократизмом, а также выявить круг общественных деятелей, занимавшихся теоретической и практической разработкой общей программы действий [26. С. 96-97]. В основном речь идет о публицистах «Русской мысли», «Вестника Европы» и «Русского богатства» двух последних десятилетий XIX - начала XX в. (К.Д. Кавелин, В.А. Гольцев, К.К. Арсеньев, А.Д. Градовский, Н.К. Михайловский, В.Г. Короленко, А.В. Пешехонов, В.А. Мякотин и др.).

Эвристическая значимость либерально-демократического синтеза: поиск механизма, позволяющего предложить национальный проект «демократизации без революции» или «реформаторской демократии». По точному замечанию Р.А. Арсланова, к началу 1880-х гг. определенная часть народников разочаровывается не только в идее насилия как движущей силы прогресса, но в народе как носителе начал демократии и социализма, и осознает, что главным субъектом модернизации страны является либерально-демократическая интеллигенция, действующая на легальной почве. С другой стороны, многие русские либералы после воцарения Александра III утрачивают веру в реформаторский потенциал самодержавия и признают необходимость адаптации своих западных идеалов к реалиям русской жизни для обретения более прочной социальной базы. Все это предопределило их сближение в 80 -е гг. XIX в. [27. C. 10,$16 ; 28$. C. 52].

Описывая взаимоотношения народников и либералов, Р.А. Арсланов не скрывает наличия между ними непримиримых разногласий, прежде всего по вопросу об особом пути развития России. Именно на этой основе он выделяет две модели реформаторского демократизма: либерально-демократическую - западный путь к свободе через создание «социального государства», и реформаторски-народническую - самостоятельный путь к сочиальной справедливости в союзе с народом [29. С. 55]. Но были и важные точки соприкосновения, вокруг которых кристаллизовались основные компоненты идеологии реформаторского демократизма. Это особое отношение к народу (признание ответственности интеллигенции за его «бедственное» положение), совместная деятельность в земстве как базовом институте национальной демократической системы и лучшей школе подготовки населения страны к политической свободе и демократии и, наконец, убеждение в необходимости мирной эволюции страны путем постепенного преодоления социальных издержек Великих реформ [27. С. 9, 10]. 
Главное условие дальнейшего развития реформ преодоление раскола между властью, обществом и народом. Эту миссию представители реформаторскодемократического направления отводили так называемой «передовой» русской интеллигенции. В совместной статье Р.А. Арсланова и В.В. Блохина анализируется позиция по этому вопросу либералов К.Д. Кавелина и А.Д. Градовского на рубеже 1870-1880-х гг. и последователей Н.К. Михайловского начала XX в. - А.В. Пешехонова и В.А. Мякотина. Несмотря на то, что их концепции интеллигенции возникли в разные исторические периоды, авторы статьи находят в саморефлексии либералов и неонародников ряд общих черт. Это признание внесословной природы русской интеллигенции и, соответственно, наличие у нее общенародной задачи продолжения легальной борьбы с существующим в стране политическим режимом во имя свободы и демократии [23. С. 33].

Практическое развитие идеи либерально-демократического синтеза в годы первой русской революции рассматривается в статье М.Н. Мосейкиной на примере Партии демократических реформ (М.М. Ковалевский, И.И. Иванюков, К.К. Арсеньев и др.). Автор оценивает ее деятельность как первую попытку создания в стране либеральной партии «почвенного» типа, допускающей сохранение монархии при условии ее «решающего» участия в разрешении социальных проблем общества [30. С. 37]. Здесь уместно было бы вспомнить, что концепцию «народной монархии» отстаивали не только либеральные демократы, но и некоторые бывшие народники вроде Л.А. Тихомирова. Однако из-за взаимного недоверия между властью и обществом, посеянного цареубийством 1 марта 1881 г., эта и многие другие инициативы представителей реформаторской демократии оказались нежизнеспособными.

Подводя итог обзору публикаций в «Вестнике Российского университета дружбы народов. Серия: История России», мы можем констатировать, что перед нами, пожалуй, единственное периодическое издание, в котором продолжается традиция изучения истории «классического» русского народничества. Общее ко- личество выявленных нами авторов и публикаций относительно невелико. Но сила данного авторского коллектива не в числе, а в наличии у него устойчивого ядра из трех ведущих отечественных историков реформаторско-демократической мысли - Р.А. Арсланова, В.В. Блохина и В.В. Зверева. Во многом именно их усилиями в современном народниковедении утвердился и продолжает развиваться новый, более объективный подход к пониманию явления народничества как типу сознания, идеологии и движения в среде русской демократической интеллигенции, отстаивавшей доктрину самобытной модернизации страны.

Еще одна важная заслуга авторов рассмотренных публикаций - смещение акцента в изучении народничества с революционного на легально-реформаторское крыло, благодаря чему народники начинают восприниматься не как «лишние люди» и «отщепенцы», а как созидательная общественная сила, нацеленная на преодоление социокультурного раскола между образованным обществом и народом.

Среди конкретных проблем, поставленных на страницах журнала за последние десять лет, прежде всего следует выделить анализ специфики реформаторского демократизма народников и его влияния на другие модели общественного переустройства России (т.е. на либералов, марксистов и др.). В серии статей на эту тему авторы последовательно и доказательно проводят мысль, что в 80-90-е гг. XIX в. народничество постепенно освобождается от идеализации народа и эволюционирует по пути признания невозможности построения в стране подлинно демократического общества без предварительного обеспечения свободы личности. И это действительно важнейший показатель зрелости народнической мысли.

Общность исследовательских задач и подходов к их решению позволяет утверждать, что вокруг журнала «Вестник Российского университета дружбы народов. Серия: История России» уже давно сложился серьезный научный коллектив, не только отражающий, но и во многом определяющий новые направления в изучении русского народничества.

\section{ЛИТЕРАТУРА}

1. Василий Федорович Антонов. Памяти учителя : воспоминания и статьи / под ред. В.М. Козьменко. М. : РУДН, 2015. 236 с.

2. Мокшин Г.Н. Народничество как идеология самобытной модернизации России // Вестник Воронежского государственного университета. Сер. История. Политология. Социология. 2015. № 4. С. 77-80.

3. Тюкачев Н.А. Отечественная историография революционного народнического движения 1869-1880-х гг. Брянск : Курсив, 2010. 304 с.

4. Тюкачев Н.А. Народничество в освещении российских «охранителей» самодержавия // Вестник Российского университета дружбы народов. Сер. История России. 2010. № 1. С. 74-89.

5. Зверев В.В. Реформаторское народничество в отечественной дореволюционной историографии // Вестник Российского университета дружбы народов. Сер. История России. 2008. № 4. С. 55-71.

6. Зверев В.В. Реформаторское народничество и проблема модернизации России. От сороковых к девяностым годам ХІХ в. М. : Уникум-Центр, 1997. $366 \mathrm{c.}$

7. Зверев В.В. Драматическая история историографического феномена: как «мирные народники» превратились в «мелкобуржуазных реакционеров» // Вестник Российского университета дружбы народов. Сер. История России. 2009. № 3. С. 5-22.

8. Мокшин Г.Н. В.И. Харламов и становление современной историографии правого народничества // Вестник Российского университета дружбы народов. Сер. История России. 2015. № 1. С. 43-57.

9. Мосейкина М.Н. Трудовая народно-социалистическая партия в современной отечественной историографии // Вестник Российского университета дружбы народов. Сер. История России. 2009. № 1. С. 47-60.

10. Пирумова Н.М. Социальная доктрина М.А. Бакунина. М. : Наука, 1990. 320 с.

11. Жукова Н.А. М.А. Бакунин и его идеи в немецкой анархической печати первой трети ХХ в. // Вестник Российского университета дружбы народов. Сер. История России. 2015. № 1. С. 9-20.

12. Жукова Н.А. Теория русского анархизма в западногерманской историографии конца 1960-1980-х гг. // Вестник Российского университета дружбы народов. Сер. История России. 2014. № 2. С. 45-57. 
13. Зверев В.В. Реформаторское народничество и проблема модернизации России. От сороковыХ к девяностым годам ХІХ в. : автореф. дис. ... д-ра ист. наук. М., 1997. 36 с.

14. Блохин В.В. Становление доктрины «либерального социализма» Н.К. Михайловского : автореф. дис. ... д-ра ист. наук. М., 2006. 41 с.

15. Мокшин Г.Н. Идейная эволюция легального народничества во второй половине XIX - начале XX вв. : автореф. дис. ... д-ра ист. наук. Саратов, 2010. $42 \mathrm{c}$.

16. Блохин В.В. Идеолог реформаторского народничества Николай Михайловский: проблема формирования мировоззрения // Гуманитарные науки и образование. 2010. № 2. С. 100-105.

17. Блохин В.В. «...Все-таки впереди огни»: реформаторский демократизм В.Г. Короленко // Вестник Российского университета дружбы народов. Сер. История России. 2010. № 4. С. 25-37.

18. Зверев В.В. Марксистские идеи в интерпретации переводчика «Капитала» на русский язык // Вестник Российского университета дружбы народов. Сер. История России. 2014. № 3. С. 14-24.

19. Зверев В.В. Отголоски «теории малых дел» в начале ХХ в. (на примере попечительной деятельности Г.П. Сазонова) // Вестник Российского университета дружбы народов. Сер. История России. 2016. № 3. С. 29-38.

20. Мокшин Г.Н. Основные этапы истории «культурного» народничества // Вестник Российского университета дружбы народов. Сер. История России. 2016. № 2. С. 19-28.

21. Пашков А.М. Политическая ссылка и развитие краеведения на Русском Севере в XIX - начале XX в.: опыт переосмысления // Вестник Российского университета дружбы народов. Сер. История России. 2011. № 2. С. 112-126.

22. Арсланов Р.А., Климашин А.Л. Периодические издания России рубежа XIX-XX вв. о социальной адаптации русских переселенцев в Средней Азии // Вестник Российского университета дружбы народов. Сер. История России. 2017. № 3. С. 347-363.

23. Арсланов Р.А., Блохин В.В. Интеллигенция в воззрениях российских либералов и реформаторов-демократов конца ХІХ - начала ХХ в. // Вестник Российского университета дружбы народов. Сер. История России. 2014. № 2. С. $22-36$.

24. Зверев В.В. Могло ли народничество быть консервативным? (к постановке проблемы) // Задавая вопросы прошлому... М. : Гуманитарий, 2006. C. $58-71$.

25. Блохин В.В. Очерки истории народнической мысли второй половины XIX века. М. : Современная экономика и право, 2009.212 с.

26. Арсланов Р.А. О гранте РГНФ «Эволюция реформаторской демократической мысли России во второй половине ХІХ - начале ХХ вв.: модели развития, историография и методы исследования» // Вестник Российского университета дружбы народов. Сер. История России. 2009. № 2. C. 95-99.

27. Арсланов Р.А. Становление и эволюция реформаторского демократизма в России конца XIX - начала XX в. // Вестник Российского университета дружбы народов. Сер. История России. 2011. № 2. С. 5-22.

28. Арсланов Р.А. Становление модели реформаторского демократизма в творчестве русских мыслителей второй половины ХІХ в. // Вестник Российского университета дружбы народов. Сер. История России. 2008. № 4. С. 39-54.

29. Арсланов Р.А. Реформаторский демократизм в концепции В.А. Гольцева // Вестник Российского университета дружбы народов. Сер. История России. 2010. № 1. С. 42-59.

30. Мосейкина М.Н. К вопросу об альтернативных моделях модернизации России: Партия демократических реформ начала ХХ в. // Вестник Российского университета дружбы народов. Сер. История России. 2011. № 1. С. 27-39.

Mokshin Gennady N. Voronezh State University (Voronezh, Russia). E-mail: mok410@mail.ru

CURRENT PROBLEMS OF STUDYING HISTORY OF RUSSIAN POPULISM IN "RUDN JOURNAL OF RUSSIAN HISTORY" IN 2008-2017

Keywords: historiography; populism; intelligentsia; reform democracy; personal freedom.

The researchers of Russian populism know V.F. Antonov's school very well. Its representatives (doctors of historical sciences R.A. Arslanov, V.V. Blokhin, V.V. Zverev, V.A. Isakov, N.A. Tyukachev, etc.) made a significant contribution to the establishment of the modern populism studies. Thanks to their efforts, the journal, which has been published since 2002 at the Department of Russian History of the Peoples' Friendship University of Russia (RUDN University), has become one of the leading centres for studying history and historiography of Russian populism.

The purpose of the article is to highlight the contribution of RUDN University historians and their colleagues from Bryansk, Voronezh and Petrozavodsk to the research of the topical problems of the modern populism studies. The author has analyzed twenty articles published in the "RUDN Journal of Russian History" in 2008-2017. In addition, there are considered the generalizing works on the history of Russian populism, which characterize the present state of its historiography.

All the publications are divided according to three topics: domestic and foreign historiography of populism; history of the right wing of populism and the ideological evolution of late populism.

The articles of N.A. Tyukachev, V.V. Zverev, G.N. Mokshin, N.A. Zhukova and M.N. Moseykina are devoted to populism historiography. There is emphasized the modern authors' special interest in the pre-revolutionary studies of populism, which previously received little attention, as well as interest in the phenomenon of Marxist historiography - the so-called "liberal populism".

The ideology and practice of the right (non-revolutionary) populism was considered in the articles of V.V. Zverev, V.V. Blokhin, G.N. Mokshin, A.M. Pashkov, R.A. Arslanov and A.L. Klimashin. Most authors are focused on the controversy between the populists-politicians and the populists-culturalists over the tactics of transforming the country, as the disagreements on this issue are the key to the typology of the trends and the periodization of the history of the right populism.

Another important topic studied in the journal is the analysis of the specifics of the populists' reform democracy and its influence on other models of the social reorganization of Russia (liberals, Marxists, etc.). In the articles on this topic written by R.A. Arslanov, V.V. Blokhin and M.N. Moseykina, there is highlighted the idea that in the 1880-1890s populism was gradually being freed from the idealization of the people and was evolving along the path of recognizing the impossibility of building a genuinely democratic society in the country without ensuring personal freedom.

In conclusion, there is given an overall assessment of the efforts of the authors of the "RUDN Journal of Russian History" to develop a new approach to the understanding of Russian populism as the ideology of Russia's original modernization. Particular attention is paid to shifting the emphasis in the study of populism from the revolutionary wing to the legally reformatory wing, thanks to which populists were perceived not as "superfluous people" and "renegades", but as a creative social force aimed at overcoming the socio-cultural split between the educated society and the people.

Another important topic studied in the journal is the analysis of the specifics of the populists' reform democracy and its influence on other models of the social reorganization of Russia (liberals, Marxists, etc.). In the articles on this topic written by R.A. Arslanov, V.V. Blokhin and M.N. Moseykina, there is highlighted the idea that in the 1880-1890s populism was gradually being freed from the 
idealization of the people and was evolving along the path of recognizing the impossibility of building a genuinely democratic society in the country without ensuring personal freedom.

In conclusion, there is given an overall assessment of the efforts of the authors of the "RUDN Journal of Russian History" to develop a new approach to the understanding of Russian populism as the ideology of Russia's original modernization. Particular attention is paid to shifting the emphasis in the study of populism from the revolutionary wing to the legally reformatory wing, thanks to which populists were perceived not as "superfluous people" and "renegades", but as a creative social force aimed at overcoming the socio-cultural split between the educated society and the people.

\section{REFERENCES}

1. Kozmenko, V.M. (ed.) (2015) Vasiliy Fedorovich Antonov. Pamyati uchitelya: vospominaniya i stat'i [Vasily Fedorovich Antonov. In memory of the teacher: memories and articles]. Moscow: RUDN.

2. Mokshin, G.N. (2015) Populism as an ideology of Russia modernization. Vestnik VGU. Seriya: Istoriya. Politologiya. Sotsiologiya - Proceedings of Voronezh State University. Series: History. Political science. Sociology. 4. pp. 77-80. (In Russian).

3. Tyukachev, N.A. (2010) Otechestvennaya istoriografiya revolyutsionnogo narodnicheskogo dvizheniya 1869-1880-kh gg. [Russian historiography of the revolutionary Narodnik movement of the 1869-1880s]. Bryansk: Kursiv.

4. Tyukachev, N.A. (2010) Russian radical preservators of monarchy about populism. Vestnik Rossiyskogo universiteta druzhby narodov. Seriya: Istoriya Rossii-RUDN Journal of Russian History. 1. pp. 74-89. (In Russian).

5. Zverev, V.V. (2008) The image of reformative populism (narodnitchestvo) in the works of Russian pre-revolutionary historians. Vestnik Rossiyskogo universiteta druzhby narodov. Seriya: Istoriya Rossii - RUDN Journal of Russian History. 4. pp. 55-71. (In Russian).

6. Zverev, V.V. (1997) Reformatorskoe narodnichestvo i problema modernizatsii Rossii. Ot sorokovykh $k$ devyanostym godam XIX v. [Reformer Populism and the Problem of Modernization of Russia. From the Forties to the Nineties of the Nineteenth Century]. Moscow: Unikum-Centr.

7. Zverev, V.V. (2009) The image of reformative populism (narodnichestvo) in Russian historiography from the 1920 s to the early 21 th century. Vestnik Rossiyskogo universiteta druzhby narodov. Seriya: Istoriya Rossii-RUDN Journal of Russian History. 3. pp. 5-22. (In Russian).

8. Mokshin, G.N. (2015) V.I. Kharlamov and the formation of modern historiography of right-wing populism. Vestnik Rossiyskogo universiteta druzhby narodov. Seriya: Istoriya Rossii - RUDN Journal of Russian History. 1. pp. 43-57. (In Russian)

9. Moseykina, M.N. (2009) Ideology and Practice of Labour Populist-Socialistic Party in a Modern Russian Historiography. Vestnik Rossiyskogo universiteta druzhby narodov. Seriya: Istoriya Rossii - RUDN Journal of Russian History. 1. pp. 47-60. (In Russian).

10. Pirumova, N.M. (1990) Sotsial'naya doktrina M.A. Bakunina [Social Doctrine of M.A. Bakunin]. Moscow: Nauka.

11. Zhukova, N.A. (2015) Mikhail Bakunin and his ideas in the German anarchist press in the first third of 20th century. Vestnik Rossiyskogo universiteta druzhby narodov. Seriya: Istoriya Rossii-RUDN Journal of Russian History. 1. pp. 9-20. (In Russian).

12. Zhukova, N.A. (2014) Theory of Russian anarchism in the West German historiography in the late 1960s-1980s. Vestnik Rossiyskogo universiteta druzhby narodov. Seriya: Istoriya Rossii-RUDN Journal of Russian History. 2. pp. 45-57. (In Russian).

13. Zverev, V.V. (1997) Reformatorskoe narodnichestvo i problema modernizatsii Rossii. Ot sorokovykh $k$ devyanostym godam XIX v. [Reformer Populism and the Problem of Russian Modernization. From the forties to the nineties of the nineteenth century]. Abstract of the History Dr. Diss. Moscow.

14. Blokhin, V.V. (2006) Stanovlenie doktriny “liberal'nogo sotsializma” N.K. Mikhaylovskogo [Formation of N.K. Mikhailovsky' liberal socialism doctrine]. Abstract of the History Dr. Diss. Moscow.

15. Mokshin, G.N. (2010) Ideynaya evolyutsiya legal'nogo narodnichestva vo vtoroy polovine XIX - nachale XX vv. [The ideological evolution of legal populism in the second half of the 19th - early 20th centuries]. Abstract of the History Dr. Diss. Saratov.

16. Blokhin, V.V. (2010) Ideolog reformatorskogo narodnichestva Nikolay Mikhaylovskiy: problema formirovaniya mirovozzreniya [Nikolai Mikhailovsky as an ideologist of reformative populism: problems of the world outlook formation]. Gumanitarnye nauki i obrazovanie. 2. pp. 100-105.

17. Blokhin, V.V. (2010) And still there are lights in front of us: the reformatory democratism of V. Korolenko. Vestnik Rossiyskogo universiteta druzhby narodov. Seriya: Istoriya Rossii-RUDN Journal of Russian History. 4. pp. 25-37. (In Russian).

18. Zverev, V.V. (2014) Marxist ideas in interpretation of "Capital"'s translator into Russian. Vestnik Rossiyskogo universiteta druzhby narodov. Seriya: Istoriya Rossii - RUDN Journal of Russian History. 3. pp. 14-24. (In Russian).

19. Zverev, V.V. (2016) Echo of the "modest causes theory" in early 20th century (the case of G.P. Sazonov's trusteeship). Vestnik Rossiyskogo universiteta druzhby narodov. Seriya: Istoriya Rossii-RUDN Journal of Russian History. 1. pp. 29-38. (In Russian).

20. Mokshin, G.N. (2016) Main stages of history of "cultural” populism. Vestnik Rossiyskogo universiteta druzhby narodov. Seriya: Istoriya Rossii RUDN Journal of Russian History. 2. pp. 19-28. (In Russian).

21. Pashkov, A.M. (2011) Political exile and Development of Local Studies in Northern Russia in 19th - early 20th Centuries: Experience of Rethinking. Vestnik Rossiyskogo universiteta druzhby narodov. Seriya: Istoriya Rossii-RUDN Journal of Russian History. 2. pp. 112-126. (In Russian).

22. Arslanov, R.A. \& Klimashin, A.L. (2017) Russian Periodicals at the turn of the 19th - 20th centuries on Russian migrants' sociocultural adaptation in Central Asia. Vestnik Rossiyskogo universiteta druzhby narodov. Seriya: Istoriya Rossii - RUDN Journal of Russian History. 3. pp. 347-363. (In Russian).

23. Arslanov, R.A. \& Blokhin, V.V. (2014) Intelligentsia in views of Russian liberals and reformers-democratic of late 19th - early 20th centuries. Vestnik Rossiyskogo universiteta druzhby narodov. Seriya: Istoriya Rossii-RUDN Journal of Russian History. 2. pp. 22-36. (In Russian).

24. Zverev, V.V. (2006) Moglo li narodnichestvo byt' konservativnym? (k postanovke problemy) [Could Populism be conservative? (to the statement of the problem)]. In: Zakharov, V.N. (ed.) Zadavaya voprosy proshlomu... [Asking questions to the past...]. Moscow: Gumanitariy. pp. 58-71.

25. Blokhin, V.V. (2009) Ocherki istorii narodnicheskoy mysli vtoroy poloviny XIX veka [Essays on the history of Narodnik thought of the second half of the 19th century]. Moscow: Sovremennaya ekonomika i pravo.

26. Arslanov, R.A. (2009) About Grant of the RHSF "Evolution of the reformatory democratic thought of Russia in the second half of the 19th - early 20th centuries: development models, the historiography and research methods". Vestnik Rossiyskogo universiteta druzhby narodov. Seriya: Istoriya Rossii-RUDN Journal of Russian History. 1. pp. 95-99. (In Russian)

27. Arslanov, R.A. (2011) Formation and evolution of reformatory democratism in Russia late 19th -early 20th centuries. Vestnik Rossiyskogo universiteta druzhby narodov. Seriya: Istoriya Rossii - RUDN Journal of Russian History. 2. pp. 5-22. (In Russian).

28. Arslanov, R.A. (2008) Reformation-democratic model's forming in works of Russian thinkers of the second part of 19 th century. Vestnik Rossiyskogo universiteta druzhby narodov. Seriya: Istoriya Rossii - RUDN Journal of Russian History. 4. pp. 39-54. (In Russian).

29. Arslanov, R.A. (2010) Reformatory democratism in the concept of V. Goltsev. Vestnik Rossiyskogo universiteta druzhby narodov. Seriya: Istoriya Rossii-RUDN Journal of Russian History. 1. pp. 42-59. (In Russian).

30. Moseykina, M.N. (2011) The problem of alternative models of Russian modernization: Russian Democratic Reforms Party's ideology in early 20th century. Vestnik Rossiyskogo universiteta druzhby narodov. Seriya: Istoriya Rossii - RUDN Journal of Russian History. 1. pp. 27-39. 